\title{
1. Leaving Gravesend at Last, or Introducing Strindberg to England
}

'Address for the time being: Gravesend by London 12 Pelham Road. (England) Best wishes to your brother and sister Yrs. August Sg' [IX, 191]. This hastily written and unpunctuated message appears on an undated postcard from Strindberg to his eldest daughter, Karin, now living with her mother, Siri von Essen, in Finland. Strindberg had seen neither his three children nor his first wife since leaving Sweden in September 1892 for what was to prove an extended self-exile spent mainly in Germany, Austria and France. Here, however, he was keeping his first family tenuously in touch with his movements following his recent second marriage to the young Austrian journalist Frida Uhl. The ceremony had taken place on Heligoland in May 1893, with two local pilots as witnesses, because the recent cessession of the island to Germany in 1890 meant that British marriage regulations still obtained there, and no banns were required. Now he and Frida had proceeded to England to enjoy (though that is hardly the word to describe so disastrous a venture) a combination of business trip and honeymoon.

England - or 'die Fraueninsel' as he described it in an equally laconic note to the Finland-Swedish author Adolf Paul [IX, 196; 2, 457] - has rarely been closely associated with Strindberg, either during his lifetime or since, and the three weeks that he spent there in 1893, firstly in Gravesend, where he and Frida came ashore, and then in London where they lived in Pimlico, at the home of the theatre director J.T. Grein, are emblematic of the difficulty with which he has subsequently found acceptance here.

Strindberg's immediate problems stemmed in part at least from Grein. He had been encouraged to leave Germany by the latter's vague promise to mount a production of The Father at his recently established Independent Theatre, where it would be a Scandinavian follow-up to the production of Ibsen's Ghosts with which the theatre had opened the previous year. However, although he advertised Strindberg's play among his future repertoire on the playbill for his inaugural production, Grein failed whatever promise he may have given. In fact he travelled abroad during the time Strindberg spent in London and he would later write that he could neither find an English actress prepared to play 
the part of Laura nor obtain the Lord Chamberlain's permission to put the play on in the first place.

Problems also arose where the publisher William Heinemann was concerned. Strindberg not only believed that Heinemann was prepared to publish his sequence of five meditative poems Somnambulistic Nights in Broad Daylight (1884-90); he also thought that he was interested in commissioning English editions of some of his novels. Heinemann seems to have had no such serious intention, however, and Strindberg's initial enthusiasm for England as the latest of several promised lands in his career rapidly deteriorated. 'England is a southern country,' he had written to Paul, shortly after arriving in Gravesend, 'with roses high on the house walls even at Whitsuntide, laurels in flower as tall as two men and enormous, real chestnut trees!' [IX, 198]. But within a month the entire country had become for him a 'robbers' nest'. He informed Paul that he had been 'on the brink of getting rabies in all the heat and pit coal' [IX, 215], and, without waiting to see any of his schemes mature, he hurried back to the more familiar ground of Germany. Moreover, as so often in his career, business failure rapidly soured his personal relationships, this time with Frida who ominously remained behind in London 'to take care of [the] theatres and publishers' [IX, 215]. For having studied at a convent school in Hampstead a few years earlier, she spoke the language fluently, unlike Strindberg, whose poor English left him at an infuriating disadvantage.

For many years Strindberg's prospects in England hardly improved. The first of his plays to reach the English stage, for example, was The Stronger, in 1906. It was played to little acclaim, and when, three years later, it was performed again at His Majesty's Theatre on 9 and 10 December 1909 together with Act Five of Ostrovsky's Vassilissa Melentieva, this was not on Strindberg's account but because in the role of the silent Mlle Y it provided the celebrated Russian actress Lidija Jarvorskaja (the Princess Bariatinsky) with a vehicle which could not be impaired by her as yet imperfect grasp of English. ${ }^{1}$ Moreover, when he was performed on his own account the early critical reception, which dismissed his plays as 'too personal', 'unbalanced', 'hate-filled', 'egotistical', 'morally questionable', 'mad', the work of 'a charlatan, more disagreeable in mind than Ibsen', 'irredeemably pessimistic' and 'without any sense of humour', articulates a response that has, unfortunately, changed little over the years. ${ }^{2}$ 'It is a waste of time to translate into English plays like... Strindberg's The Creditors,' observed a reviewer of The Incorporated Stage Society's 1912 production of the play in Elie Schleussner's translation, 'They do not amuse, interest, or instruct ${ }^{3}-$ a response which is sometimes echoed even by so experienced and able a translator of his plays as Michael Meyer, in his major biography of Strindberg (1985). Meyer concludes that with the exception of one or two works that can flourish with the right performer or audience 
only nine of Strindberg's plays remain performable today, and of these several require careful cutting. Furthermore, he adds that Strindberg's novels (with the exception of The People of Hemsö) and the autobiographical books (with the exception of Inferno) are of little interest outside Sweden, except perhaps in Germany where, according to Meyer, 'even the best of that country's novelists have often shared Strindberg's faults.' ${ }^{\text {' }}$

One begins to see why Strindberg, unlike, for example, Ibsen and Chekhov, has made comparatively little headway in this country. Whereas their major plays were domesticated to the British stage with relative ease, and were eagerly seized upon as performance vehicles by actors both then - at the end of the nineteenth century - and now, in regular revivals with star-studded casts, Strindberg has remained an elusive figure, at best only partially known. Whereas both Ibsen and Chekhov rapidly found advocates for their respective series of dramas on themes from contemporary life (and few playwrights have been received by performers with as much excitement as Ibsen, notwithstanding the public opprobrium he initially provoked), Strindberg's seemingly far less coherent oeuvre makes him very much more difficult to pin down. Apart from the fifty-seven odd plays written for the most part in four main bursts between 1869 and 1909, his work includes seven novels, twelve volumes of short stories on both contemporary and historical themes, several works of history, including, in the two-volume The Swedish People, the first major history of Sweden narrated from an ethnographic perspective, ten volumes of autobiography plus his recently published Occult Diary, numerous studies in natural science (including botany, chemistry and geology as well as alchemy), works of poetry, satire and linguistics alongside numerous essays on politics, art, psychology and other subjects - and this is not to mention either the twenty-two volumes of his extant correspondence or his important experimental work as a painter and photographer.

Moreover, even if a comparison is restricted to their work for the theatre, Ibsen and Chekhov, having discovered the basic format of their major sequences of plays on contemporary subjects then continued to work with a similar dramatic structure, which they developed and refined but did not essentially change, whereas Strindberg, having started out (like Ibsen) writing historical drama, including Master Olof in 1872, first established himself as a major naturalist with The Father, Miss Julie and Creditors in the late 1880s, and then remade, or reinvented, himself as a writer in order to return to the theatre in 1898 with To Damascus, the first of what he would subsequently call his 'dream plays' [SV 46, 7]. At the same time he also embarked upon the most significant sequence of historical dramas since Schiller and Shakespeare (eleven plays on Swedish themes and four on 'World-Historical subjects', all written between 1899 and 1909), wrote morality plays about crime and punishment 
like Advent (1898), plays with rustic settings like The Virgin Bride (1901) and Midsummer (1900), a Parisian boulevard drama like Crimes and Crimes (1898), and the four principal chamber plays of 1907, including The Ghost Sonata and The Pelican.

Strindberg's first English reviewers were not, of course, aware of this multifacetedness. Nor could they have been. They had only a few, generally compromised translations on which to base their misunderstandings. Many of these first translations were made not from the original Swedish but from Emil Schering's German versions, themselves frequently open to question, and there was no one on hand to undertake his transposition into English as there was with William Archer for Ibsen or Constance Garnett for Chekhov. This neglect compares significantly with Strindberg's substantial reputation in Germany during the first twenty-five years of this century or the attention paid to him in France following the Second World War, where Roger Blin's 1949 production of The Ghost Sonata was an important precursor for his staging of Waiting for Godot in 1953, ${ }^{5}$ and even though the situation improved considerably when Elizabeth Sprigge and Michael Meyer provided reliable translations of a number of the major play texts in the 1960s, several of the most important dramas have still not found an established place on the English stage, and many of the novels and other prose works remain untranslated. Thus, The Pelican was performed for the first time in this country by an amateur group at Leeds University as late as $1950,{ }^{6}$ and The Virgin Bride still awaits its English stage premiere in spite of Michael Meyer's twenty-five-year-old, actable translation. The Ghost Sonata, meanwhile, had its English premiere in 1926 but was not performed again professionally for fifty years while To Damascus has still not been presented as a whole, even though Part One was performed once during the 1930s and again in 1975 at the Traverse Theatre in Edinburgh, where it was praised by Alien Wright in The Scotsman as 'a play so packed with ideas and invective that it makes most contemporary dramas seem trivial.'

In contrast to Ibsen and his magisterial entry into the British theatrical tradition Strindberg's arrival has therefore been halting and slow. Apart from his disturbing variety, there are several reasons why this should have been so. The first to present Strindberg and his theories on drama to an English-reading public was the energetic Irish politician and man-of-letters, Justin Huntly McCarthy, who contributed an incomplete translation of the Preface to Miss Julie to The Gentleman's Magazine in August 1892, and a longer essay, in which Strindberg was praised as the most prominent Scandinavian dramatist after Ibsen, to The Fortnightly Review, the following month. As usual, Strindberg was quick to respond to such attention. His letters indicate that he was a reader of this well-respected journal during the 1880s and when he became aware of McCarthy's article, he promptly brought it to the attention of his current 
French translator, Charles de Casanove: 'Finally just a couple of words to assist your efforts and to lend a little weight to your thinking about my writing. The Fortnightly Review in London, a highly esteemed journal, has just published an essay on $M^{\text {lle }}$ Julie, written by M. Justin Huntly McCarthy. It is very favourable (I have read it), which surprises me with regard to the puritanism of chaste England' [IX, 73]. He then referred his young friend Birger Mörner to this pioneering analysis of his work, which Mörner would, in a somewhat reduced form, eventually publish in Swedish translation in En bok om Strindberg, the pioneering collection of essays on Strindberg's work that he edited, together with Gustaf Fröding, in 1894. As was so often the case, Strindberg functioned here as his own, considerable impresario.

However, apart from McCarthy Strindberg lacked an influential supporter in leading English literary circles during these crucial early years. While Ibsen had important advocates among established writers like Henry James, new talents like James Joyce, or men of letters like Edmund Gosse and William Archer, both of whom knew Norwegian and, especially in Archer's case, proved crucial to his acceptance, there was no one who played a similar role where Strindberg was concerned. 'C'est du Nord aujourd'hui que nous vient la lumière' - many had occasion to quote Voltaire's words here and there in Europe at this time, but where England was concerned, there could be only a single such source of light, and that was Ibsen.

Which is not entirely to overlook George Bernard Shaw. As a friend of both Grein and Archer, a familiar of London's leading actors and (particularly) actresses, and a follower of the independent theatre movement for which he also wrote, Shaw was certainly aware of Strindberg. His sister, Lucie Carr Shaw, assisted in the translation from Schering's German version of Miss Julie for its first English performance by The Adelphi Play Society in April 1912. And Shaw's own admiration for, and curiosity about, Strindberg was so great that he visited him in Stockholm in July 1908. Together with his wife, Charlotte, Shaw met him at the recently opened Intimate Theatre where Strindberg's co-director August Falck and the latter's wife, Manda Björling, had been hastily recalled by Strindberg from their summer holidays to take part in a private morning performance of the play for the Shaws and himself. It was thus in Shaw's company that Strindberg saw his most celebrated play on stage for the first time (although he had been present in Copenhagen for its world premiere in 1889, it seems he did not watch the performance at the Copenhagen University Student Union in which Siri von Essen played the role of Julie). This may explain why, just before she went on stage, he should have asked Björling as Julie to 'take the whole thing a little easily, otherwise it'll upset me so.' ${ }^{8}$ As it was, the performance ended in praise from Strindberg to Björling for her 'great, beautiful and truthful acting' [XVII, $10 ; 2,792$ ], 
doubts from Shaw's side about the viability of a théâtre intime of this kind, and on Strindberg's part a typical dénouement. For he appears to have been greatly irritated by Shaw's wife and her polite conversation and when he could bear it no longer, he announced pointedly that in ten minutes time he would have an acute attack of his 'secret illness'. Or as Shaw described it, in a postcard to William Archer: 'After some conversation, consisting mainly of embarrassed silences and a pale smile or two by A.S. and floods of energetic eloquence in a fearful lingo, half French, half German, by G.B.S., A.S. took out his watch and said, in German: "At two o'clock I am going to be sick." The visitors accepted this delicate intimation and withdrew.'

In spite of this intermezzo, Shaw continued to take an interest in Strindberg's plays. In March 1910, for example, he wrote again to Strindberg asking his permission, on Sir Herbert Beerbohm Tree's behalf, to mount a production of his early (1882) fairy-tale play, Lucky Peter's Journey, at His Majesty's Theatre. According to Shaw, the play would suit a theatre which had recently enjoyed great success with both J.M. Barrie's Peter Pan and Maeterlinck's L'Oiseau bleu. Strindberg seems to have been understandably concerned to draw Shaw's attention to other possibilities, and in particular to his later, more radical work. For, as Björn Meidal points out [XVIII, 258], a further letter to Strindberg from Shaw, dated 29 March 1910, suggests that he had replied to Shaw's proposal with a copy of the recently written The Black Glove and also drawn his attention to both The Virgin Bride and The Dance of Death. Neither of these would sit easily with Peter Pan, of course, and Shaw wrote back:

If Lycko Per is what you describe it to me, you must have been inspired directly by heaven to write it for... the British public.... It seems to me that the best thing you can do is to let Tree have Lycko Per on condition that it is not to be produced until he has performed Svarta Handsken [The Black Glove], or whatever other play you may select, at the Afternoon Theatre...; Unfortunately I cannot read Swedish; but I see that a good deal of Svarta Handsken is in verse. This is a terrible difficulty.... If Totentanz and Kronenbraut are in prose, perhaps it might be better to suggest them. ${ }^{10}$

However, although he might act as an intermediary in this way, Shaw wrote no 'Quintessence of Strindberg' or anything comparable to his Quintessence of Ibsenism, which was to colour the English view of Ibsen for so many years. Moreover, while it is open to the reader to trace possible echoes of Strindberg in Shaw's plays, there was no dramatist writing in England on whose work Strindberg's dramaturgy had imprinted itself as deeply as it had, for example, on Eugene O'Neill's in the United States. The nearest is perhaps Sean O'Casey who wrote to the actor Robert Loraine: 'Strindberg, Strindberg, Strindberg, the greatest of them all... Barrie sits mumbling as he silvers his little model 
star and golds his little model suns, while Strindberg shakes flame from the living planets and the fixed stars. Ibsen can sit serenely in his Doll's House, while Strindberg is battling with his heaven and his hell'.11 But then no British playwright of the period had the kind of opportunities to discover Strindberg that Emil Schering's translations and Max Reinhardt's productions of his work afforded their contemporaries in Germany. According to Edward Gordon Craig, who also visited Strindberg in Stockholm, though with scant return for his efforts, ${ }^{12}$ Schering 'talked, walked, breathed and lived nothing but Strindberg', and Reinhardt's versions of The Pelican, The Dance of Death, A Dream Play and The Ghost Sonata had an important part to play in helping to create the modern movement in the theatre. ${ }^{13}$ Moreover, if the British theatre lacked its Reinhardt, there was also no English Antoine, Lugné-Poë or Vakhtangov to put on his plays, as they had done in France and Russia, where Erik XIV, with Michael Chekhov in the title role, was performed at the Moscow Arts Theatre in 1921.

Another reason for Strindberg's faltering introduction to England is the immediate constituency to which his plays might have appealed. Again, the comparison with Ibsen is instructive. Among those who first accepted Ibsen with alacrity were actresses such as Janet Achurch, Florence Farr and Elizabeth Robins. Like Karl Marx's daughter, Eleonora Aveling, who translated $A$ Doll's House, An Enemy of the People and The Lady from the Sea into English, Robins also learnt some Norwegian in order to get her hands on his plays as soon as possible for, seeking the rights to stage them, she could not wait until they had been translated. Robins played the central female role in the first English production of several of Ibsen's plays including Hedda Gabler, Hilde Wangel and Ella Rentheim. Her correspondence with Henry James betrays just how exciting it was to wait for a new Ibsen play to arrive. 'Actors were coming to realize that "Ibsen made reputations", she remarked. 'What you won't be able to imagine (unless you are an actress in your twenties) is [simply] the joy of having in our hands... such glorious and actable stuff.' ${ }^{14}$ Moreover, there was an obvious link between the plays that she and her colleagues admired and their predicament as women. Many of these actresses were involved in the suffragette movement, and Ibsen's plays not only gave them exciting parts but roles and images with which they could identify.

On the other hand, Strindberg was handicapped by his reputation as Ibsen's misogynistic antithesis. What could easily be taken for the first serious attempt to engage with Strindberg's ideas in English - a contribution that appeared well-informed because it was based on personal experience - was a chapter on 'The Women Haters, Tolstoy and Strindberg' in We Women and Our Authors (1899), the English version of a German study written by Strindberg's old continental enemy, Laura Marholm-Hansson. Certainly no one at that time 
appears to have learnt Swedish in order to read Strindberg. When a writer like George Egerton (born Mary Chavelita Dunne) looked elsewhere in Scandinavia than to Ibsen for inspiration in her collection of stories Keynotes (1893), it was to Bjørnson or Hamsun (whom she also translated) that she turned, rather than to Strindberg.

Strindberg's principal reputation rests with his plays, of course. But without a stable performance tradition, of the kind that has emerged in Germany and (on occasion) in France as well as in Scandinavia, it is impossible to fully realise his dramaturgy. For the last one hundred and twenty years the English performance tradition has been dominated by realism whereas the tradition which made Strindberg a major figure in the European theatre German expressionism - has never had any real success in England. The really significant Strindberg productions in England can be counted almost on the fingers of one hand: Robert Loraine as the Captain in The Father in 1927, Michael Redgrave and Trevor Howard in the same role in 1948 and 1964, Olivier as Edgar in The Dance of Death in 1967, Mike Ockrent's production of To Damascus in 1975 and Suzanne Bertish as Tekla in Creditors in 1986. Miss Julie was not performed outside the private theatres before 1939 because the censor denied the play a public licence, and the title role has never been identified with a major English actress. As Michael Meyer rightly points out, in an essay on Strindberg's reception on the English stage, there is an essential difference between English and Swedish performance styles:

In the Swedish theatre, as in the German, the unforgivable sin is to underact. In England, it is to overact; how often have we not seen our best actors, when faced by the peaks of Othello and King Lear, take refuge in gentlemanly underplaying or the evasiveness of theatrical fireworks? It is no coincidence that the only two actors who have fully succeeded in Strindberg in England, Robert Loraine and Wilfrid Lawson, have been actors of most unEnglish, one might almost say continental vehemence, and consequently difficult to cast in roles of ordinary human dimensions. For a parallel reason, there has never yet... been an adequate Miss Julie in England. ${ }^{15}$

Indeed, the following anecdote may be taken as symptomatic. When Loraine was to play the role of the Captain and read The Father aloud to his wife for the first time, she is said to have fallen to her knees before him when he was no more than half way through the text and assured him in passionate tones that his children were his own, and that he was not to believe a word of the play. To which Loraine is supposed to have responded: 'If it upsets you like that, there must be something in it. ${ }^{36}$

Finally, it is worth noting that Strindberg lacked not only a viable theatre and an energetic translator to give him the kind of foundation provided by 
Reinhardt and Schering during the early years of the century in Germany or someone to take on the role assumed by Archer and then by Shaw in Ibsen's case in Britain: he also had to do without the kind of academic understanding he received in the United States where at least three important studies of his work had been published by the close of the 1930s, only one of them on his plays. Even today, C.A. Helmecke's Buckle's Influence on Strindberg, Harry V. Palmblad's Strindberg's Conception of History and Carl E.W.L. Dahlström's Strindberg's Dramatic Expressionism, are all still worth consulting, ${ }^{17}$ whereas of the few books on Strindberg published in Britain before the centenary of his birth in 1949 the same might be said only of Joan Bulman's study of Shakespeare's influence on Strindberg's history plays, Strindberg and Shakespeare, which appeared in 1933. Otherwise the only works in book form that might give the English reader pause are (possibly) Lizzy Lind af Hageby's personally coloured but interesting August Strindberg. The Spirit of Revolt from 1913, which was reviewed in The Academy as 'a book in defense of one who needs it, ${ }^{18}$ and the English version of Frida Uhl's still more personal and compromised Strindbergs andra hustru which appeared as Marriage with Genius, in 1937. Indeed, as late as 1962, he continued to be compared (by F.L. Lucas) to Ibsen and was as usual found wanting as a 'maniac misogynist' who 'tended to debase the world's moral currency' and possessed 'very little sense of the value of sense'. Lacking any notion of irony, Lucas, who at one point wishes the characters of Tennessee Williams's Cat on a Hot Tin Roof condemned to 'a humane and efficient gas-chamber', now subjects Strindberg to the kind of opprobrium once lavished on Ibsen, at the end of the nineteenth century. Thus, he concludes, of one of Strindberg's most artistically achieved works, the comic novel The People of Hemsö: 'There is not a single attractive character no touch of that human warmth, sympathy and compassion that pervade the work of finer minds. All Strindberg's gifts of style and imagination, here also, are cheated of real excellence by his warped and poisoned personality'. ${ }^{19}$

This volume seeks in small measure to redress some of this neglect, and certainly to counterbalance the vituperation of men like Lucas. All of the essays are concerned, either deliberately or by default, with facilitating a re-evaluation of Strindberg in the English-speaking world. Taken together with the letters translated in the two-volume collection of Strindberg's Letters, ${ }^{\prime 20}$ in which Strindberg is placed within a Scandinavian as well as a European context, and is given the space he always claimed should be his to tell his own story, they consider a number of subjects rarely addressed before, at least in English (for example, his painting and his thoughts on acting and directing), while they also provide further discriminations on his autobiographical practice and the way in which he designed his life in order to reproduce himself in language and on stage. 
The focus in all these essays is principally on Strindberg the writer, however, not his biography, and my concern is with his artistry even when his attention turns (as it so often does) to his own autobiographical image. Only two items here are concerned solely with the plays, and one of those is a comparative study, which places Strindberg at the outset of a theatrical tradition that issues in the claustrophobic dramas of Samuel Beckett. The remainder circle around several recurring themes, including his frequent self-dramatization and the attempt, to which Strindberg is continually drawn, to represent himself in language, on the one hand, and to his obsessive concern with plots and plotmaking, both on the stage and in his own life, on the other. Moreover, this urgent search for consonance and order in which he seeks confirmation of that universal and personal masterplot that would endow his private experience with meaning is closely linked to the third of my main concerns and the central event in this life, namely his so-called Inferno crisis of the mid-1890s which emerges here as a peripeteia partly stage-managed by Strindberg himself in order that he might, not least by his experiments as a painter, replace the literary naturalism of the 1880s in, for example, Miss Julie and The Son of a Servant, with the modernist aesthetic of To Damascus, Inferno and A Dream Play. This was Strindberg's most remarkable achievement as a writer. For while he occupies a position alongside Zola and Ibsen, on the one hand, he is inescapably linked with Witkiewicz and Beckett, on the other. It is an achievement in the theatre commensurate with that of Freud in converting nineteenth-century psychology into psychoanalysis and Schoenberg's substitution of the twelve-tone scale for the building blocks of romanticism in music; thus the way in which Strindberg, almost uniquely, effected this transition between the documentary tendencies of a naturalism he so frequently interpreted in terms of his own image and a modernism engaged in finding a language in which to articulate the new inwardness it was preoccupied in mapping, is a central concern in almost every one of these essays.

Meanwhile the final essay, on 'Acting Women', serves perhaps as a kind of penance for devoting so much time to Strindberg, the 'woman-hater'. But while it is true that the latter is mentioned in it only in passing, the examination of the idea of character and the nature of the performing (supposedly female) self with which this essay is concerned, is related to reflections elsewhere in this volume on the autobiographical self by Strindberg in, for example, The Son of a Servant, and to his eloquent account of the characterless, modern character in the Preface to Miss Julie. 'As modern characters living in an age of transition more urgently hysterical at any rate than the one that preceded it,' he writes there,

I have depicted the figures in my play as more split and vacillating, a mixture of the old and the new, and it seems to me not improbable that 
modern ideas may also have permeated down by way of newspapers and kitchen talk to the level of the servants.... My souls (characters) are conglomerates of past and present stages of culture, bits out of books and newspapers, scraps of humanity, torn shreds of once fine clothing now turned to rags, exactly as the human soul is patched together... [SV 27, $104-5]$

This modern self, which Strindberg first properly identified in the self-analysis he conducted in order to write The Son of a Servant, informed both his principal genres (the plays and his letters) in which he continually divided, multiplied and masked himself in a complex ontological game. When he is at his apparently most direct and self-revelatory he may well be diverting attention skilfully away from something even more significant while when he writes a seemingly more objective portrait of 'someone else' (Miss Julie, for example, or Gustaf Trolle in The Protector of the Realm (Riksförestandaren of 1909), he can be at his most obliquely self-revealing. ${ }^{21}$ Moreover, as he recognizes himself, in concluding his autobiography [SV 21, 215], when he transposes himself so single-mindedly into language he in fact disperses himself among the pages of his books, from where he emerges to solicit the reader's attention as a multiple figure of the text. Similarly, in a widely prevalent trope about the nature of acting, an actor likewise disperses himself among his parts. Thus, both the autobiographical writer and the actor appear to have liberated themselves from their physical, empirical existence and abandoned themselves promiscuously to a world of signs without firm reference points.

And here is the great paradox of Strindberg's project: the 'truth teller' (or 'sanningsägaren') that he so often aspired to be is linked to a theatricality that is commonly associated with the creation of dubious illusion and hypocrisy. Moreover, the transparency of the self at which (following Rousseau) the autobiographer might be presumed to be aiming is obscured by the art of feigning and dissembling at which the actor excels. Character, as Strindberg discovers, is a role, or rather, not a singular identity but a multiplicity of incarnations which ensure a fundamental instability that he both detests (when it manifests itself in the form of an actress, like his alter ego's partner, Maria, in the autobiographical fiction A Madman's Defence (1887-8), who lives 'an actress's dissolute life' $)^{22}$ and yet recognizes in himself, in his own existential variety, where it becomes precisely that troublesome and dangerous modernity that is associated, towards the end of the nineteenth century, with (among other things) the feminine, the theatre and what Nietzsche calls 'the hocuspocus of the actor. ${ }^{23}$

Originally written to the moment, for the more or less fugitive world of conferences and inaugural lectures, I have occasionally adapted an essay so that it might find a more natural place alongside its companions in this volume. I 
have also corrected a number of errors and infelicities and taken some account of subsequent scholarship, my own and other people's, but I have resisted the temptation that publication in book form brings of a wholesale rewriting. In any case these essays are of a piece with my earlier study Strindberg and Autobiography. Writing and Reading a Life (Norwich, 1986) and my more recent editorial scholarship with the two-volume Strindberg Letters (London and Chicago, 1994) and Strindberg's Essays (Cambridge, 1996), and share with them the preoccupations explored here.

My thanks to the universities of Amsterdam, Birmingham, Cambridge, East Anglia, Helsinki, Stockholm and Washington, and to the Gorky Institute in Moscow, the Royal Dramatic Theatre in Stockholm and the Adelbert Stifter Institute in Linz, where I was first given the opportunity of approaching these topics. My thanks also to those colleagues with whom I have had the chance of discussing the ideas advanced here. To Margareta Brundin, the curator of the Strindberg collection in the Royal Library in Stockholm, I am indebted both for the generous help she has always extended me over many years when consulting Strindberg's manuscripts, and for the illustrations included here. 